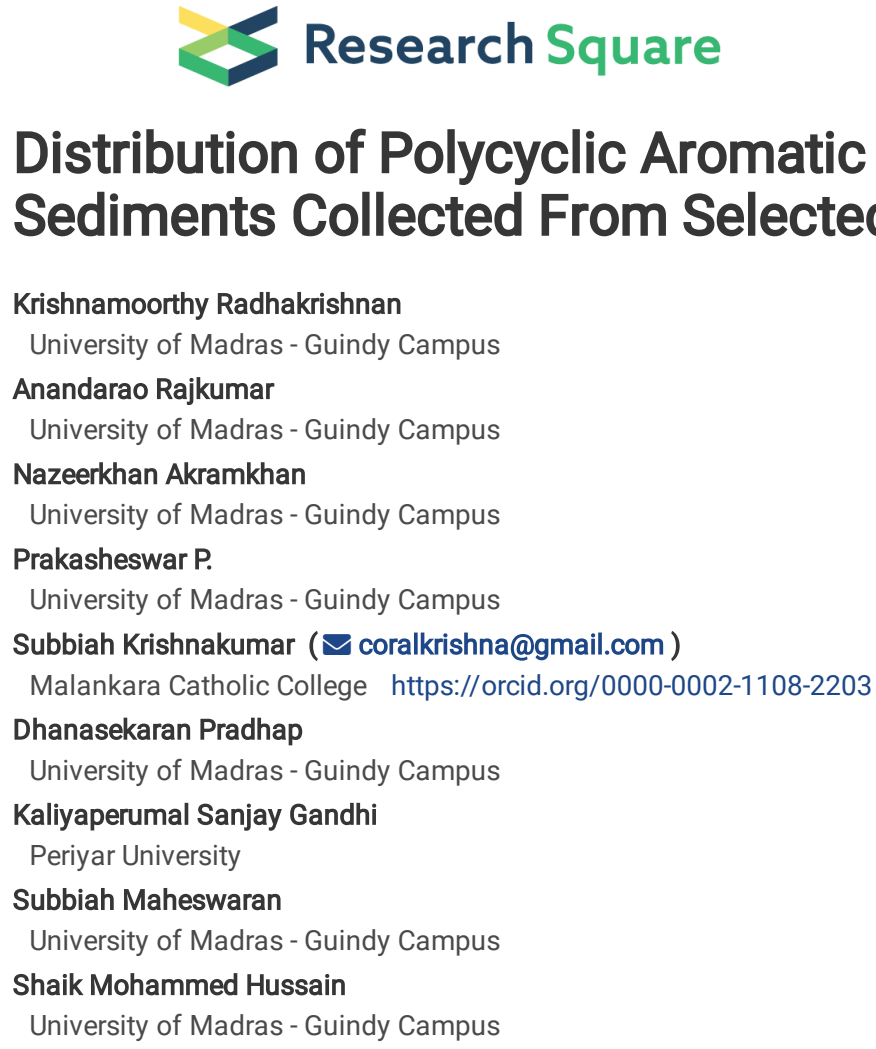

Krishnamoorthy Radhakrishnan

University of Madras - Guindy Campus

Anandarao Rajkumar

University of Madras - Guindy Campus

Nazeerkhan Akramkhan

University of Madras - Guindy Campus

Prakasheswar P.

University of Madras - Guindy Campus

Subbiah Krishnakumar ( $\nabla$ coralkrishna@gmail.com )

Malankara Catholic College https://orcid.org/0000-0002-1108-2203

Dhanasekaran Pradhap

University of Madras - Guindy Campus

Kaliyaperumal Sanjay Gandhi

Periyar University

Subbiah Maheswaran

University of Madras - Guindy Campus

Shaik Mohammed Hussain

University of Madras - Guindy Campus

\title{
Distribution of Polycyclic Aromatic Hydrocarbons (PAHs) in Surface Sediments Collected From Selected Estuaries of Kerala, West Coast of India
}

Research Article

Keywords: Low and high molecular weight PAHs, selected estuaries, surface sediments, Total toxic equivalent

Posted Date: July 13th, 2021

DOI: https://doi.org/10.21203/rs.3.rs-632229/v1

License: @ (1) This work is licensed under a Creative Commons Attribution 4.0 International License. Read Full License 


\section{Abstract}

The investigation aims to study the source and concentration of polycyclic aromatic hydrocarbon (PAHs) fractions in the surface sediments of selected estuaries of the southwest coast of Kerala India. The concentration of PAHs ranged from 0.47 to $126.64 \mathrm{ng} / \mathrm{g}$. The estuarine sediments were enriched by HMW-PAHs and they are occupied nearly $93.76 \%$ of the total concentration, followed by LMW-PAHs (LMW-PAH - $6.23 \%$ ). The sum of surface sedimentassociated PAH distribution was higher in the inner part of the estuary, especially at Anjuthengu and Kadinamkulam estuaries. The sediment grain size and distance of the sampling point from the coast are significantly playing an important role in the distribution of the PAHs. The ratio of LMW/HMW PAHs in this study indicating that the pyrolytic process is the chief source of PAHs in the estuarine sediments. The calculated total TEQ value ranged from 0.20 to 54.80 $\mathrm{ng} / \mathrm{g}$. A comparative study suggests that the obtained TEQ value was less than the other locations of India and worldwide.

\subsection{Introduction}

Numerous studies have reported that polycyclic aromatic hydrocarbons (PAHs) are recognized as notable carcinogens mutagens and ubiquitous contaminants in a wide variety of mediums including air, food, sediments, and water. A wide variety of Solid-liquid extraction (SLE) methods was used to solve components of interest from solid samples such as soil or sediments using a suitable solvent. Various modes of SLE techniques such as maceration, ultrasonic-assisted extraction (UAE), microwave-assisted extraction (MAE), Soxhlet extraction (SE), and accelerated solvent extraction (ASE) were applied to extract this compound from chosen environmental samples (Ghassempour et al. 2008; Madej et al. 2018). The choice of the extraction procedure depended on several influential factors such as capital and operating cost, operation simplicity, required amount of organic solvent required, and the availability of a standardized method (Dean et al. 1997). The soxhlet extraction procedure was recommended by the US Environmental Protection Agency (US EPA) for extracting semi-volatile and non-volatile organics from solid matrices. However, they are arduous procedures, required a large amount of solvent, and not suitable for separating the thermally degradable compounds (De Castro et al. 1998).

The ultrasonic probe extraction procedure is an efficient method especially for their high extraction efficiency, lower equipment costs, ease of operation, little sample preparation, lower extraction temperatures, and suitability for trace level organic compounds in soil and sediments (Song et al. 2002; Banjoo et al. 2005). However, the efficiency of this method is depending on the solvent or solvent composition, extraction time, sample load, and water content (Berset et al. 1999). According to Sun et al. 1998, acetone was found to be the most efficient solvent for extracting the US EPA listed 16 priority pollutant PAHs in soils. The loss of hydrocarbon compounds by nearly $16 \%$ was observed during oven drying of samples at $45^{\circ} \mathrm{C}$ (Wong et al. 1980; Berset et al. 1999). The notable systematic study on dynamics of polycyclic aromatic hydrocarbons (PAHs) in surface sediments was reported at Cochin estuary by Ramzi et al. 2017. The present study aims to report the concentration of 16 USEPA listed PAHs in surface sediments of selected estuaries, west coast of Kerala, India

\subsection{Study area}

Kerala coastal area has been endowed with an expansive body of brackish waters including backwaters, lagoons, and estuaries including mangrove swamps. The chain of backwaters from south to north of the Kerala coast is interconnected by an extensive network of canals and they have played a significant role in the socio-economic status and cultural history of Kerala. Among the chain of backwaters, we selected four backwaters (Kayals means backwaters) namely Kadinamkulam, Anchuthengu, Kappil-Hariharapuram, Kayamkulam.

Kadinamkulam Kayal lying in between Lat $8^{\circ} 35$ to $8^{\circ} 45 \mathrm{~N}$ and Long $76^{\circ} 45$ to $76^{\circ} 56 \mathrm{E}$ in the Thiruvananthapuram district. This is connected to the Veli Kayal on the southern side by the Parvathyputhanar canal and the Anchuthengu Kayal on the northern side through the lower reaches of the Vamanapuram River. Kadinamkulam backwater is connected with the sea only during the rainy season through the opening of the sand bar at Perumathura. Kappil-Hariharapuram Kayal is lying between $8^{\circ} 77^{\prime} 75.90^{\prime \prime}$ to $8^{\circ} 78^{\prime} 88.13^{\prime \prime} \mathrm{N}$ latitudes and $76^{\circ} 67^{\prime} 58.48^{\prime \prime}$ to $76^{\circ} 67^{\prime} 68.83^{\prime \prime} E$ longitudes. This backwater system receives freshwater input from the small river called Ayiroor Puzha. This Kayal is connected with Paravur Kayal through the Maniyamkulam canal. Kappil Kayal is widely used for fishing, retting, recreation, aquaculture, etc. Kayamkulam Kayal is a narrow stretch brackish water body, which is lying between $9^{\circ} 2^{\prime}$ and $9^{\circ} 12^{\prime} \mathrm{N}$ latitude and $76^{\circ} 26^{\prime}$ and $76^{\circ} 32^{\prime} E$ longitude. During flood season, this canal system was filled with fresh water from the Pampa and Achankoil River. Kayamkulam sand bar was developed parallel to the Kayal due to the tidal influence of the Arabian Sea. Ayirumthengu mangrove ecosystem was flourished in the southern low-lying areas of Kayamkulam Lake. This mangrove ecosystem was richly vegetated by Rhizophora sp., Avecenniasp. and Acanthus sp.

\subsection{Material And Methods}

\subsection{Sampling and Pre-treatment process}

The surface sediments were collected from selected estuaries of the Kerala coast using a grid-based sampling method (Fig. 1). The sampling grid was created using the grid index features tool of Arc GIS 10.3. The pre-created grid plot was tracked by Locus Map Free (Version 3.50.1). The geographical coordinates of the sampling points were extracted from the KMZ extension file of the Arc GIS software package. Twenty surface sediments were collected from three selected estuaries of the Kerala coast (Kayamkulam, Anchuthengu, Kadinamkulam, and Varkala-Hariharapuram estuaries). The collected surface sediment was transferred to amber-colored glass jars using a pre-clean stainless steel spatula and kept in the icebox. The sediments were immediately transferred into the laboratory and kept under $-20^{\circ} \mathrm{C}$ in a deep freezer until analysis. The textural characteristics of the sediment (sand, silt, and clay) were determined by pipette analysis (Folk, 1980) in wet sediments. The surface sediments were freeze-dried, homogenized, and powdered using an agate mortar and pestle. The surface sediments were treated with $1 \mathrm{~N} \mathrm{HCl}$ and washed with double distilled water to remove salts and carbonates. The concentration of organic matter (OM) was estimated by exothermic heating followed by oxidation with potassium dichromate and concentrated $\mathrm{H}_{2} \mathrm{SO}_{4}$. An excess amount of dichromate was titrated against $0.5 \mathrm{~N}$ of ferrous ammonium sulfate (Gaudette et al., 1974).

\subsection{Separation and analysis of PAHs}

Page 2/10 
The sonication/ultrasonic agitation method was used to obtain higher extraction efficiencies during the extraction of the PAH fraction (Sun et al. 1998). Hence, the freeze-dried and homogenized sediment was used to extract the PAH with dichloromethane - methanol (2:1 ratio) solvent mixture in a

sonication/ultrasonic agitation bath for $48 \mathrm{~h}$ and the obtained extract was treated with activate granular copper to remove the sulfur impurities. Finally, the extracted solution was evaporated using the rotary evaporation method and the extract was purified using the silica-alumina (2:1 ratio) column cleanup method. Later, the column was eluted with n-hexane to remove the aliphatic compounds followed by PAH compounds were eluted by n-hexane dichloromethane mixture (3:7 ratio). The final extract was evaporated by a gentle nitrogen stream and the near-dryness extract was prepared for PAH determination using $500 \mu \mathrm{l} \mathrm{n}$-hexane. The USEPA listed sixteen PAHs were analyzed using a flame ionization detector on an Agilent $7890 \mathrm{~B}$ Series Gas Chromatograph. The column temperature for analyses was initially programmed from $60^{\circ} \mathrm{C}$ (initial time, $2 \mathrm{~min}$ ) at a rate of $10^{\circ} \mathrm{C}$ per min, $120-300^{\circ} \mathrm{C}$ at a rate of $3^{\circ} \mathrm{C}$ per min, and held at $310^{\circ} \mathrm{C}$ for $5 \mathrm{~min}$. The injector and detector were kept at $280^{\circ} \mathrm{C}$ and $325^{\circ} \mathrm{C}$ respectively and the injection volume was $2 \mu \mathrm{L}$ during both injection modes. The extraction efficiency was cross-checked based on the recovery output of the known amount of PAH standard mixture. The recovery of PAHs varied between $82 \%$ and $95 \%$. All the chemical analyses were done in triplicates and output results are expressed on a dry weight basis. The sum of the $\mathrm{PAH}$, high and low molecular weight rings, and potential toxic equivalent as shown in bar charts.

\subsection{Results And Discussion}

\subsection{Concentration of LMW and HMW ring PAHs}

The studied PAH fractions were classified as low molecular weight PAHs (2 and 3 rings) and high molecular weight PAHs (4 and above rings). The name of the studied PAH fractions, the number of rings, concentration range, mean, standard deviation, Toxic Effects-Range Low (ERL), Toxic Effects-Range Medium (ERM), Carcinogenic potency, and molecular weight of each PAHs were shown in Table 1. The surface sediments of the estuaries were dominated by finegrained silt to clay grade fractions and few samples from the mouth of the estuaries were exhibiting sandy nature. The total PAH concentration ranges from 0.47 to $126.64 \mathrm{ng} / \mathrm{g}$, with a mean value of $15.08 \mathrm{ng} / \mathrm{g}$. In detail, the low molecular weight rings (LMW rings -2 \& 3 rings) in the sediments range from 0 to 5.42 $\mathrm{ng} / \mathrm{g}$, whereas heavy molecular weight rings (HMW rings $-4 \&$ above rings) concentration ranges from 5.42 to $122.1 \mathrm{ng} / \mathrm{g}$. The estuarine sediments were enriched by HMW-PAHs and they are occupied nearly $93.76 \%$ of the total concentration, followed by LMW-PAHs (LMW-PAH - 6.23\%). Among the LMW ring PAHs, Naphthalene, Acenaphthene, and Anthracene was detected as a high enriched compound, whereas HMW-PAHs was enriched by Benzo(b)fluoranthene,

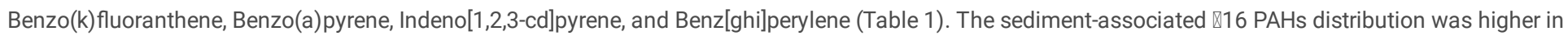
the inner part of the estuary, especially at Anjuthengu and Kadinamkulam estuaries. Similar studies on the Cochin estuary also supported that the distance of the sampling point from the estuary mouth and inundated seawater also act as a controlling factor of the distribution of PAHs. The enrichment of PAHs in the inner part of the estuarine system was indirectly affected by sediment characteristics, fluvial and tidal flow processes. According to Safe, 1998, benzo[a]pyrene is one of the most toxic of the parent PAH, and this compound is used as a surrogate chemical marker for genotoxic organic compounds. The possible source of the PAHs was due to the proximity of anthropogenic activities such as road run-off and/or combusted particulates from vehicles or possibly the railway tracks (Vane et al. 2020). According to the previous studies, the relationship between the organic carbon/natural organic matters including humic substance coasting in the mineral surface directly affected the distribution of PAHs (Stout and Emsbo-Mattingly, 2008; Ukalska Jaruga et al., 2018). Further, this investigation suggests that the relationship between TOC and PAHs showing a positive correlation in sediment cores. The negative correlation significance was shown in between grain size (sand-silt and clay ratio) from the Mersey estuary (Vane et al., 2007), whereas $\triangle \mathrm{PAHs}$ in sediment and pore water of the Yellow river China showing a positive relationship with silt and fine grain fractions. The surface sediments of this study suggesting a similar observation especially in the inner part of the estuaries, where the sediment is enriched with fine fractions (Yu et al. 2009; Maruya et al. 1996; Maruya et al. 1997).

The PAHs reached the marine environment through both the high-temperature pyrolytic processes and the petrogenic source (Xu et al. 2007). The rapid increase of PAHs in the Cochin estuary was chiefly controlled by monsoonal changes, land/river runoff, and the combustion of pyrolytic source materials. Further, the reported total PAH concentration of the Cochin estuary was 100 times higher than in the present study. A comparative study of PAHs in sediments was compared with previously reported investigations of India and worldwide. The earlier studies on PAH distribution in aquatic ecosystems were significantly affected by sediment texture, organic content, and flow characteristics (He et al., 2014; Kumar et al., 2016; Vane et al. 2020). The concentration of PAHs in selected estuaries of the west coast was lower than in the other study region.

PAHs in sediments could cause liver neoplasm and other abnormalities in bottom-dwelling fish (Malins et al. 1988; Vethaak et al. 1992), and with delayed hatching, induction of deformities, disruption of larvae swimming activity, and DNA damage (Cousin and Cachot, 2014). The ratio between low molecular weight and high molecular weight PAH fractions can be used to identify the sources of PAH. The calculated ratio was $>1$ indicates the petrogenic source of $\mathrm{PAH}$, whereas ratio $<1$ indicates the pyrolytic source. In this study, the ratio of LMW/HMW PAHs indicating that pyrolytic fractions dominate in these estuaries.

NOAA's sediment quality guideline was widely applied to determine the contamination level of PAHs in the aquatic system (NOAA, 1999). Long et al. 1995 suggested the two important tools such as Effect Range Low (ERL) and Effect Range Median (ERM) to determine the sediment quality level. Both indices (ERL and ERM) were helpful to enumerate the threshold value and rarely occurring adverse biological effects. The toxicological values with their effect ranges are used to assess the sediment quality, i.e. 10th percentile represented as an effect range low (ERL) and the 50th percentile ranked as effect range medium (ERM) (Long et al. 1995). The PAH distribution in the selected estuaries of Kerala indicates that the concentration of PAHs was less than the SQGs suggested ERL and ERM values. The analytical results of PAHs concluded that the surface sediments of the selected estuarine system falling under the low contamination and low-risk category.

The sediment's toxicity range was assessed from the sum of all potential carcinogenic PAH congers (TCPAH - BaA, Chr, BbF, BkF, BaP, DbA, and InP fractions; Chen and Chen, 2011). The TCPAH values of the surface sediments of the estuaries were ranged from 16 to $44.21 \mathrm{ng} / \mathrm{g}$. The analytical value of the TCPAH was less than the SQGs reported ERL-ERM values (1373- $8410 \mathrm{ng} / \mathrm{g}$; Long et al., 1995). The potential toxicity is the toxic equivalent (TEQ) of individual PAH was derived using the following equation (Nasher et al., 2013; Li et al., 2015). 
Total TEQ $=\sum_{i} C i \times T E F i$

Where, $\mathrm{C}_{i}$ is the concentration of an individual PAH fraction and TEF $i$ is the toxicity factor of individual fractions. The TEF of BaA, Ch, BbF, BkF, BaP, IP and DbA are $0.1,0.001,0.1,0.01,1,0.1$ and 1 respectively (USEPA, 1993). The calculated total TEQ value ranged from 0.20 to $54.80 \mathrm{ng} / \mathrm{g}$ (Fig. 2 ). A comparative table of TEQ value with other study regions suggests that the obtained TEQ from this study was less than the other locations of India and worldwide (Table 4).

\subsection{Conclusion}

The outcome of the investigation suggests that the surface sediments of selected estuaries of the Kerala coast were less contaminated by other compared study areas around the world. Further, the present study area was less contaminated by polycyclic aromatic hydrocarbons (PAHs) and experiencing less ecological risk.

\section{Declarations}

Ethics approval and consent to participate

Not applicable

\section{Consent for publication}

Not applicable

\section{Availability of data and materials}

Not applicable

\section{Competing interests}

No Competing interests

\section{Funding}

No fundings received from funding agency to carry out the work

\section{Authors' contributions}

Krishnamoorthy Radhakrishnan \& Shaik Mohammed. Hussain $\quad$ : Conceptualization, Visualization

Subbiah Krishnakumar, Kaliyaperumal Sanjai Gandhi \& Dhanasekaran Pradhap : Conceptualization,Investigation, Writing - original draft

Nazeerkhan Akramkhan, Palanichamy Prakasheswar \&: Fieldwork \& Sample collection

Subbiah Maheswaran \& Anandarao Rajkumar: Investigation \& Data curation

\section{Acknowledgements}

The authors thank Dr.S.M Hussain, Professor and Head, Department of Geology, University of Madras, Guindy Campus, Chennai- 600025 for providing the laboratory facilities to carry out the analysis.

\section{References}

1. Banjoo DR, Nelson PK (2005) Improved ultrasonic extraction procedure for the determination of polycyclic aromatic hydrocarbons in sediments. J Chromatogr A 1066(1-2):9-18

2. Berset JD, Ejem M, Holzer R, Lischer P (1999) Comparison of different drying, extraction and detection techniques for the determination of priority PAHs in background contaminated soil samples. Anal Chim Acta 383(3):263-275

3. Chen CW, Chen CF (2011) Distribution, origin, and potential toxicological significance of polycyclic aromatic hydrocarbons (PAHs) in sediments of Kaohsiung Harbor, Taiwan. Mar Pollut Bull 63(5-12):417-423

4. Cornelissen G, Breedveld GD, Kalaitzidis S, Christanis K, Kibsgaard A, Oen AM (2006) Strong sorption of native PAHs to pyrogenic and unburned carbonaceous geosorbents in sediments. Environ sci Technol 40(4):1197-1203

5. Cousin X, Cachot J (2014) PAHs and fish-exposure monitoring and adverse effects from molecular to individual level. Environ Sci Pollut Res 2:1368513688

6. Crane JL (2017) Ambient sediment quality conditions in Minnesota lakes, USA: Effects of watershed parameters and aquatic health implications. Sci Total Environ 607:1320-1338 
7. Cornelissen G, Breedveld GD, Kalaitzidis S, Christanis K, Kibsgaard A, Oen AM (2006) Strong sorption of native PAHs to pyrogenic and unburned carbonaceous geosorbents in sediments. Environ Sci Technol 40(4):1197-1203

8. Dean JR, Abdullah MP, Zakaria Z (1997) Extraction of polycyclic aromatic hydrocarbons from contaminated soil using Soxhlet extraction, pressurised and atmospheric microwave-assisted extraction, supercritical fluid extraction and accelerated solvent extraction. J Chromatogr A 791(1-2):361-366

9. De Castro ML, Garcia-Ayuso LE (1998) Soxhlet extraction of solid materials: an outdated technique with a promising innovative future. Anal Chimi Acta 369(1-2):1-10

10. Essien JP, Eduok SI, Olajire AA (2011) Distribution and ecotoxicological significance of polycyclic aromatic hydrocarbons in sediments from Iko River estuary mangrove ecosystem. Environ Monit Assess 176(1-4):99-107

11. Garcia MR, Mirlean N, Baisch PR, Caramao EB (2010) Assessment of polycyclic aromatic hydrocarbon influx and sediment contamination in an urbanized estuary. Environ Monit Assess 168(1-4):269-276

12. Gaudette HE, Flight WR, Toner L, Folger DW (1974) An inexpensive titration method for the determination of organic carbon in recent sediments. J Sediment Petrol 44:249-253

13. Guzzella L, Poma G, De Paolis A, Roscioli C, Viviano G (2011) Organic persistent toxic substances in soils, waters and sediments along an altitudinal gradient at Mt. Sagarmatha, Himalayas, Nepal. Environ Pollut 159(10):2552-2564

14. Ghassempour A, Heydari R, Talebpour Z, Fakhari AR, Rassouli A, Davies N, Aboul-Enein HY (2008) Study of new extraction methods for separation of anthocyanins from red grape skins: analysis by HPLC and LC-MS/MS. J Liq Chromatogr Relat Technol 31(17):2686-2703

15. He X, Pang Y, Song XJ, Chen BL, Feng ZH, Ma YQ (2014) Distribution, sources and ecological risk assessment of PAHs in surface sediments from Guan River Estuary, China. Mar Pollut Bull 80(1-2):52-58

16. Jaward FM, Alegria HA, Galindo Reyes JG, Hoare A (2012) Levels of PAHs in theWaters, Sediments, and Shrimps of Estero de Urias, an Estuary in Mexico, and. Their Toxicological Effects Scientific World Journal

17. Kumar KSS, Nair SM, Salas PM, Peter KJP, Kumar CSR (2016) Aliphatic and polycyclic aromatic hydrocarbon contamination in surface sediment of the Chitrapuzha River, South West India. Chem Ecol 32(2):117-135

18. Li Q, Zhang X, Yan C (2010) Polycyclic aromatic hydrocarbon contamination of recent sediments and marine organisms from Xiamen Bay, China. Arch Environ Contam Toxicol 58(3):711-721

19. Li P, Xue R, Wang Y, Zhang R, Zhang G (2015) Influence of anthropogenic activities on PAHs in sediments in a significant gulf of low-latitude developing regions, the Beibu Gulf, South China Sea: distribution, sources, inventory and probability risk. Mar Pollut Bull 90(1-2):218-226

20. Lorgeoux C, Moilleron R, Gasperi J, Ayrault S, Bonté P, Lefèvre I, Tassin B (2016) Temporal trends of persistent organic pollutants in dated sediment cores: chemical fingerprinting of the anthropogenic impacts in the Seine River basin, Paris. Sci Total Environ 541:1355-1363

21. Madej K, Kalenik TK, Piekoszewski W (2018) Sample preparation and determination of pesticides in fat-containing foods. Food chem 269:527-541

22. Malins DC, McCain BB, Landahl JT, Myers MS, Krahn MM, Brown DW, Roubal WT (1988) Neoplastic and other diseases in fish in relation to toxic chemicals: an overview. Aquat Toxicol 11(1-2):43-67

23. Maruya KA, Risebrough RW, Horne AJ (1996) Partitioning of polynuclear aromatic hydrocarbons between sediments from San Francisco Bay and their pore waters. Environ sci Technol 30(10):2942-2947

24. Maruya KA, Risebrough RW, Horne AJ (1997) Partitioning of polynuclear aromatic hydrocarbons between sediments from San Francisco Bay and their pore waters. Oceanogr Lit Rev 3(44):194

25. Maskaoui K, Zhou JL, Hong HS, Zhang ZL (2002) Contamination by polycyclic aromatic hydrocarbons in the Jiulong River estuary and Western Xiamen Sea, China. Environ Pollut 118(1):109-122

26. Mzoughi N, Chouba L (2011) Distribution and partitioning of aliphatic hydrocarbons and polycyclic aromatic hydrocarbons between water, suspended particulate matter, and sediment in harbours of the West coastal of the Gulf of Tunis (Tunisia). J Environ Monit 13(3):689-698

27. Masood N, Zakaria MP, Halimoon N, Aris AZ, Magam SM, Kannan N, Mustafa S, Ali MM, Keshavarzifard M, Vaezzadeh V, Alkhadher SAA (2016) Anthropogenic waste indicators (AWIs), particularly PAHs and LABs, in Malaysian sediments: application of aquatic environment for identifying anthropogenic pollution. Mar Pollut Bull 102(1):160-175

28. NOAA (1999) Sediment Quality Guidelines Developed for the National Status and Trends Program. http://www.ccma.nos.noaa.gov/publications/sqg.pdf

29. Nasher E, Heng LY, Zakaria Z, Surif S (2013) Assessing the ecological risk of polycyclic aromatic hydrocarbons in sediments at Langkawi Island, Malaysia. Sci World J. 2013, 13

30. Oliva AL, Quintas PY, La Colla NS, Arias AH, Marcovecchio JE (2015) Distribution, sources, and potential ecotoxicological risk of polycyclic aromatic hydrocarbons in surface sediments from Bahia Blanca estuary, Argentina. Arch Environ Contam Toxicol 69(2):163-172

31. Perez-Fernandez B, Vinas L, Franco MA, Bargiela J (2015) PAHs in the Ria de Arousa (NW Spain): a consideration of PAHs sources and abundance. Mar Pollut Bull 95(1):155-165

32. Qiao M, Wang CX, Huang SB, Wang DH, Wang ZJ (2006) Composition, sources, and potential toxicological significance of PAHs in the surface sediments of the Meiliang Bay, Taihu Lake, China. Environ Int 32(1):28-33

33. Ramzi A, Rahman KH, Gireeshkumar TR, Balachandran KK, Jacob C, Chandramohanakumar N (2017) Dynamics of polycyclic aromatic hydrocarbons (PAHs) in surface sediments of Cochin estuary, India. Mar Pollut Bull 114(2):1081-1087

34. Safe SH (1998) Hazard and risk assessment of chemical mixtures using the toxic equivalency factor approach. Environ Health Perspect 106(4):10511058

Page 5/10 
35. Song YF, Jing X, Fleischmann S, Wilke BM (2002) Comparative study of extraction methods for the determination of PAHs from contaminated soils and sediments. Chemosphere 48(9):993-1001

36. Sprovieri M, Feo ML, Prevedello L, Manta DS, Sammartino S, Tamburrino S, Marsella E (2007) Heavy metals, polycyclic aromatic hydrocarbons and polychlorinated biphenyls in surface sediments of the Naples harbour (southern Italy). Chemosphere 67(5):998-1009

37. Stout SA, Emsbo-Mattingly SD (2008) Concentration and character of PAHs and other hydrocarbons in coals of varying rank - implications for environmental studies of soils and sediments containing particulate coal. Org Geochem 39(7):801-819

38. Sun F, Littlejohn D, Gibson MD (1998) Ultrasonication extraction and solid phase extraction clean-up for determination of US EPA 16 priority pollutant polycyclic aromatic hydrocarbons in soils by reversed-phase liquid chromatography with ultraviolet absorption detection. Anal Chim Acta 364(1-3):1-11

39. USEPA (1993) Provisional Guidance for Quantitative Risk Assessment of Polycyclic Aromatic Hydrocarbons. EPA/600/R-93/089. Office of Research and Development, Washington

40. Ukalska-Jaruga A, Smreczak B, Klimkowicz-Pawlas A (2018) Soil organic matter composition as a factor affecting the accumulation of polycyclic aromatic hydrocarbons. J Soils Sediment 19:1890-1900

41. Vethaak AD, Ap Rheinallt T (1992) Fish disease as a monitor for marine pollution: the case of the North Sea. Rev Fish Biol Fish 2(1):1-32

42. Vane $\mathrm{CH}$, Harrison I, Kim AW (2007) Polycyclic aromatic hydrocarbons (PAHs) and polychlorinated biphenyls (PCBs) in sediments from the Mersey Estuary. UK Sci Total Environ 374(1):112-126

43. Vane CH, Kim AW, Emmings JF, Turner GH, Moss-Hayes V, Lort JA, Williams PJ (2020) Grain size and organic carbon controls polyaromatic hydrocarbons $(\mathrm{PAH})$, mercury $(\mathrm{Hg})$ and toxicity of surface sediments in the River Conwy Estuary, Wales, UK. Mar Pollut Bull 158, 111412

44. Wong MK (1980) A study of three extraction methods for hydrocarbons in marine sediment. Mar Chem 9(3):183-190

45. Xu J, Yu Y, Wang P, Guo W, Dai S, Sun H (2007) Polycyclic aromatic hydrocarbons in the surface sediments from Yellow River, China. Chemosphere 67(7):1408-1414

46. Yu Y, Xu J, Wang P, Sun H, Dai S (2009) Sediment-porewater partition of polycyclic aromatic hydrocarbons (PAHs) from Lanzhou Reach of Yellow River, China. J hazard Mater 165(1-3):494-500

47. Zakaria MP, Takada H, Tsutsumi S, Ohno K, Yamada J, Kouno E, Kumata H (2002) Distribution of polycyclic aromatic hydrocarbons (PAHs) in rivers and estuaries in Malaysia: a widespread input of petrogenic PAHs. Environ sci Technol 36(9):1907-1918

48. Zhou JL, Hong H, Zhang Z, Maskaoui K, Chen WJWR (2000) Multi-phase distribution of organic micropollutants in Xiamen Harbour, China. Water Res 34(7):2132-2150

49. Zhang ZL, Hong HS, Zhou JL, Yu G (2004) Phase association of polycyclic aromatic hydrocarbons in the Minjiang River Estuary, China. Sci Total Environ 323(1-3):71-86

50. Zuloaga O, Prieto A, Ahmed K, Sarkar SK, Bhattacharya A, Chatterjee M, Bhattacharya BD, Satpathy KK (2013) Distribution of polycyclic aromatic hydrocarbons $\mathrm{n}$ recent sediments of Sundarban mangrove wetland of India and Bangladesh: a comparative approach. Environ Earth Sci 68(2):355-367

\section{Tables}

Table 1 concentration ranges, mean and standard deviation (S.D) of individual PAHs (ng/g) in the surface sediments, Kayals of West coast of Kerala, India 


\begin{tabular}{|c|c|c|c|c|c|c|c|c|c|}
\hline \multirow[t]{2}{*}{ S.no } & \multirow[t]{2}{*}{ Name of the PAH } & \multirow{2}{*}{$\begin{array}{l}\text { No of } \\
\text { rings }\end{array}$} & \multicolumn{5}{|c|}{ Sediment $(n=20)$} & \multirow{2}{*}{$\begin{array}{l}\text { Carcinogenic } \\
\text { potency }^{\mathrm{a}}\end{array}$} & \multirow{2}{*}{$\begin{array}{l}\text { Molecular } \\
\text { weight }\end{array}$} \\
\hline & & & $\begin{array}{l}\text { Range } \\
\text { (ng/g) }\end{array}$ & $\begin{array}{l}\text { Mean } \\
(\mathrm{ng} / \mathrm{g})\end{array}$ & $\begin{array}{l}\text { S.D. } \\
(\mathrm{ng} / \mathrm{g})\end{array}$ & ERL & ERM & & \\
\hline 1 & Naphthalene (Nap) & 2-Ring & ND - 3.99 & 0.511 & 0.987 & 160 & 2100 & D & 128.18 \\
\hline 2 & Acenaphthylene (Acy) & 3-Ring & ND & ND & ND & 44 & 640 & - & 152.2 \\
\hline 3 & Acenaphthene (Ace) & 3-Ring & ND & ND & ND & 16 & 500 & - & 154.2 \\
\hline 4 & Anthracene (Ant) & 3-Ring & ND - 2.12 & 0.106 & 0.474 & 853 & 1100 & D & 178.24 \\
\hline 5 & Phenanthrene (Phe) & 3-Ring & ND - 2.15 & 0.250 & 0.579 & 240 & 1500 & D & 178.24 \\
\hline 6 & Fluorene (FI) & 3-Ring & ND - 0.55 & 0.028 & 0.123 & 19 & 540 & D & 166.23 \\
\hline 7 & Benzo(a)anthracene (BaA) & 4-Ring & ND - 7.29 & 1.160 & 1.691 & 261 & 1600 & $\mathrm{~B}_{2}$ & 228.3 \\
\hline 8 & Chrysene (Chr) & 4-Ring & ND - 6.88 & 0.800 & 1.559 & 384 & 2800 & $\mathrm{~B}_{2}$ & 228.3 \\
\hline 9 & Fluoranthene (Flu) & 4-Ring & ND - 6.5 & 0.823 & 1.442 & 600 & 5100 & D & 202.26 \\
\hline 10 & Pyrene (Pyr) & 4-Ring & ND - 6.71 & 0.763 & 1.492 & 665 & 2600 & D & 202.26 \\
\hline 11 & Benzo(b)fluoranthene (BbF) & 5-Ring & ND - 12.19 & 1.727 & 2.692 & 320 & 1800 & $\mathrm{~B}_{2}$ & 252.32 \\
\hline 12 & Benzo(k)fluoranthene (BkF) & 5-Ring & ND - 19.7 & 1.908 & 4.405 & 280 & 1620 & $\mathrm{~B}_{2}$ & 252.32 \\
\hline 13 & Benzo(a)pyrene (BaP) & 5-Ring & ND - 21.28 & 2.211 & 4.645 & 430 & 1600 & $\mathrm{~B}_{2}$ & 252.32 \\
\hline 14 & $\begin{array}{l}\text { Dibenzo(a,h)anthracene } \\
\text { (DBA) }\end{array}$ & 5-Ring & ND - 8.68 & 0.874 & 1.974 & 63.4 & 260 & $\mathrm{~B}_{2}$ & 278.35 \\
\hline 15 & Indeno $[1,2,3-c d]$ pyrene $(\operatorname{InP})$ & 6-Ring & ND - 15.46 & 2.098 & 3.409 & - & - & $\mathrm{B}_{2}$ & 276.34 \\
\hline 16 & Benz[ghi]perylene & 6-Ring & ND - 17.41 & 1.074 & 3.951 & 430 & 1600 & D & 276.34 \\
\hline
\end{tabular}

$\mathrm{B}_{2}$ Probable carcinogen, D - not classifiable as to human carcinogenicity (USEPA carcinogenic classification ${ }^{\mathrm{a}}$ ), S.D - Standard Deviation, ND - Not detected, ERL - Toxic Effects-Range Low, ERM - Toxic Effects-Range Medium

Table 2 sample wise distribution of sand, silt and clay (in \%), low molecular and high molecular weight rings (ng/g), Total PAH (ng/g) of surface sediments, Kayals of West coast of Kerala, India

\begin{tabular}{llllllllllllllllllll} 
Location & 1 & 2 & 3 & 4 & 5 & 6 & 7 & 8 & 9 & 10 & 11 & 12 & 13 & 14 & 15 & 16 & 17 & 1 \\
\hline Sand \% & 73 & 18.2 & 73.8 & 23.6 & 96.6 & 69.6 & 86.2 & 29.4 & 83.4 & 75.2 & 13.8 & 4.2 & 85.8 & 4.6 & 2 & 42 & 2.2 & 0 \\
\hline Silt \% & 26.2 & 80.8 & 25.4 & 76 & 3 & 25.4 & 13.4 & 70.4 & 16.4 & 24.8 & 85.8 & 95.4 & 14 & 95 & 97.6 & 57.6 & 97 & 9 \\
\hline Clay \% & 0.8 & 1 & 0.8 & 0.4 & 0.4 & 5 & 0.4 & 0.2 & 0.2 & 0 & 0.4 & 0.4 & 0.2 & 0.4 & 0.4 & 0.4 & 0.8 & 0 \\
\hline $\begin{array}{l}\text { LMW } \\
\text { rings }\end{array}$ & 0 & 0.81 & 5.42 & 2.77 & 0 & 0 & 0 & 0 & 0 & 0.65 & 0 & 0 & 1.28 & 4.54 & 1.05 & 0 & 0 & 0 \\
\hline $\begin{array}{l}\text { HMW } \\
\text { rings }\end{array}$ & 1.38 & 10.16 & 11.14 & 7.56 & 0.47 & 0.8 & 1.94 & 12.68 & 3.34 & 5.68 & 19.73 & 3.33 & 27.68 & 122.1 & 8.12 & 0.51 & 3.06 & 0 \\
\hline $\begin{array}{l}\text { Total } \\
\text { PAH }\end{array}$ & 1.38 & 10.97 & 16.56 & 10.33 & 0.47 & 0.8 & 1.94 & 12.68 & 3.34 & 6.33 & 19.73 & 3.33 & 28.96 & 126.64 & 9.17 & 0.51 & 3.06 & $\wedge$ \\
\hline $\begin{array}{l}\text { Total } \\
\text { TEQ }\end{array}$ & 0.60 & 4.75 & 7.17 & 4.47 & 0.20 & 0.35 & 0.84 & 5.49 & 1.45 & 2.74 & 8.54 & 1.44 & 12.53 & 54.80 & 3.97 & 0.22 & 1.32 & 0 \\
\end{tabular}

ND - Not detected, LMW rings - Low molecular weight rings (2 \& 3 rings); HMW rings - High molecular weight rings (4 \& above rings), TEQ - Toxic equivalent Table 3 comparison table of polycyclic aromatic hydrocarbon (PAHs) in the present study and other worldwide estuarine and coastal systems report 


\begin{tabular}{|c|c|c|c|}
\hline S.no & Details of the study region & Concentration Sum of PAH & References \\
\hline 1 & Mersey Estuary, UK & $626-3766$ & Vane et al. 2007 \\
\hline 2 & Norwegian harbors, Norway & $2100-31100$ & Cornelissen et al. 2006 \\
\hline 3 & San Francisco Bay, USA & $26.1-600$ & Maruya et al. 1996 \\
\hline 4 & Tokyo Bay, Japan & $534-292370$ & Zakaria et al. 2002 \\
\hline 5 & Xiamen Harbor, China & $247-480$ & Zhou et al. 2000 \\
\hline 6 & Minjiang River Estuary, China & $112-877$ & Zhang et al. 2004 \\
\hline 7 & Jiulong River Estuary and Western Xiamen Sea, China & $59-1177$ & Maskaoui et al. 2002 \\
\hline 8 & Yellow River, China & $464-2621$ & Yu et al. 2009 \\
\hline 9 & Himalayan lakes, Nepal & $67.9 \pm 22.1$ & Guzzella et al. 2011 \\
\hline 10 & Seine River basin, France & $5000-90,000$ & Lorgeoux et al. 2016 \\
\hline 11 & Minnesota lakes, USA & $489.3 \pm 980.5$ & Crane et al. 2017 \\
\hline 12 & Cochin estuary, India & $194-14149$ & Ramzi et al. 2017 \\
\hline 13 & Chitrapuzha River, India & $5046-33087$ & Kumar et al. 2016 \\
\hline 14 & Hugli river, India & $0-1839$ & Zuloaga et al. 2013 \\
\hline 15 & Iko River estuary mangrove system, Nigeria & $6100-35,270$ & Essein et al. 2011 \\
\hline 16 & Esterode Urias, estuary, Mexico & $27-418$ & Jaward et al. 2012 \\
\hline 17 & Patos Lagoon Estuary, Brazil & $89-10451$ & Garcia et al. 2010 \\
\hline 18 & Galician estuaries, NW Spain & $44-7901$ & Perez-Fernandez et al. 2015 \\
\hline 19 & Selangor River estuary, Malaysia & $203-964$ & Masood et al. 2016 \\
\hline 20 & Selected estuaries of west coast of Kerala & Present study & \\
\hline
\end{tabular}

Table 4 Comparison of TEQ values of surface sediments of the selected estuaries of Kerala coast, Southwest coast of India with data from other areas worldwide

\begin{tabular}{lll} 
Study area & TEQ $(\mathrm{ng} / \mathrm{g})$ & References \\
\hline Naples Harbour, Italy & $2-4723$ & Sprovieri et al. 2007 \\
\hline Kaohsiung Harbor, Taiwan & $1404-1964$ & Chen and Chen, 2011 \\
\hline Bahia Blanca Estuary, Argentina & $0-1969$ & Oliva et al. 2015 \\
\hline Meiliang Bay in China & $94-856$ & Qiao et al. 2006 \\
\hline Xiamen Bay, China & $15-282$ & Li et al. 2010 \\
\hline Ría Arousa, Spain & $1.2-820$ & Perez-Fernandez et al. 2015 \\
\hline Sundarban mangrove wetland, Bangladesh & $13-1014$ & Zuloaga et al. 2013 \\
\hline Sundarban mangrove wetland, India & $1-2451$ & Zuloaga et al. 2013 \\
\hline West coastal of the Gulf of Tunis, Tunisia & $8-666.4$ & Mzoughi and Chouba, 2011 \\
\hline Cochin Estuary, India & $1-971$ & Ramzi et al. 2017 \\
\hline Selected estuaries of Kerala Southwest coast of India & $0.29-54.80$ & Present study
\end{tabular}

\section{Figures}



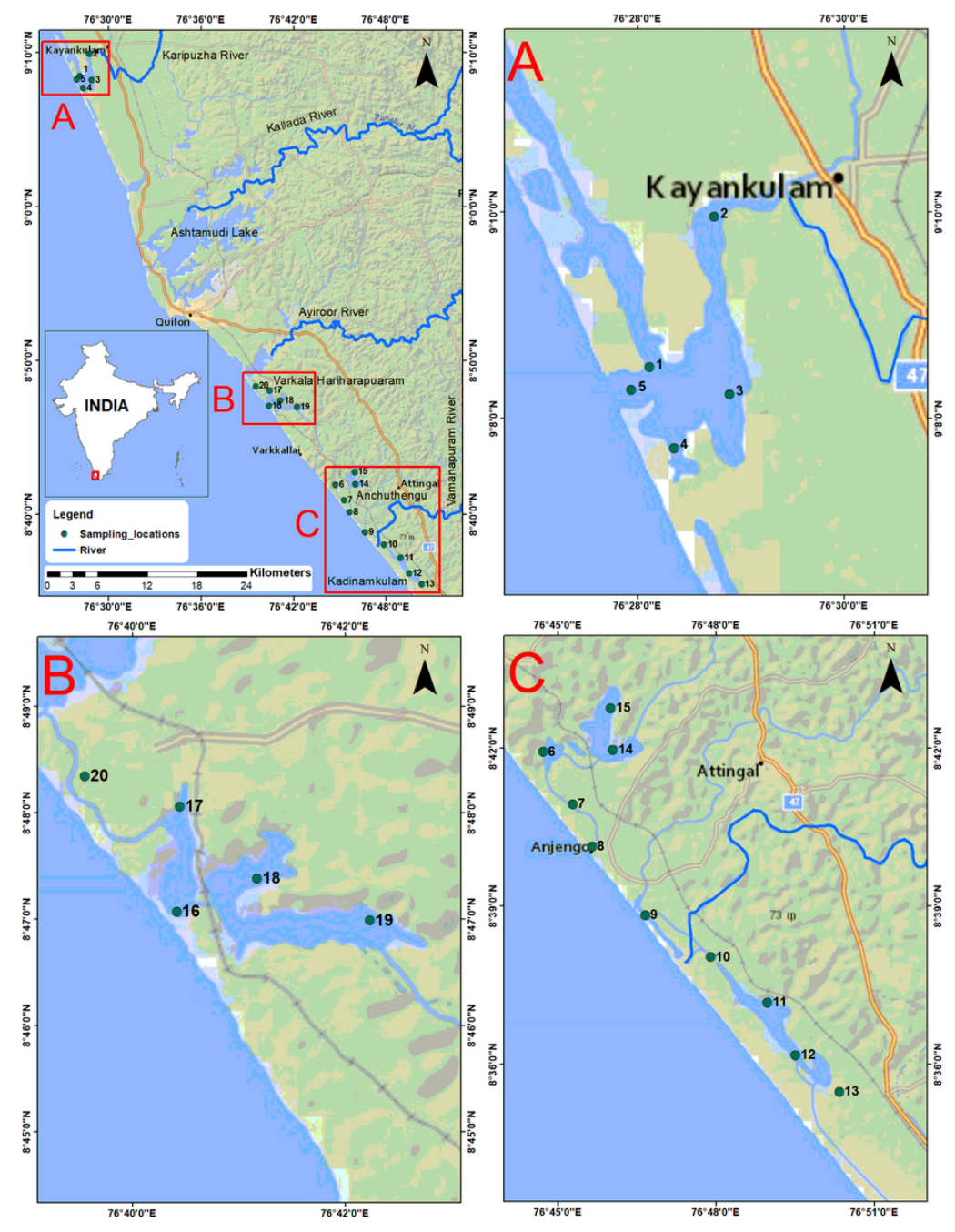

Figure 1

sampling locations and study area map of the selected estuaries of Kerala, Southwest coast of India 


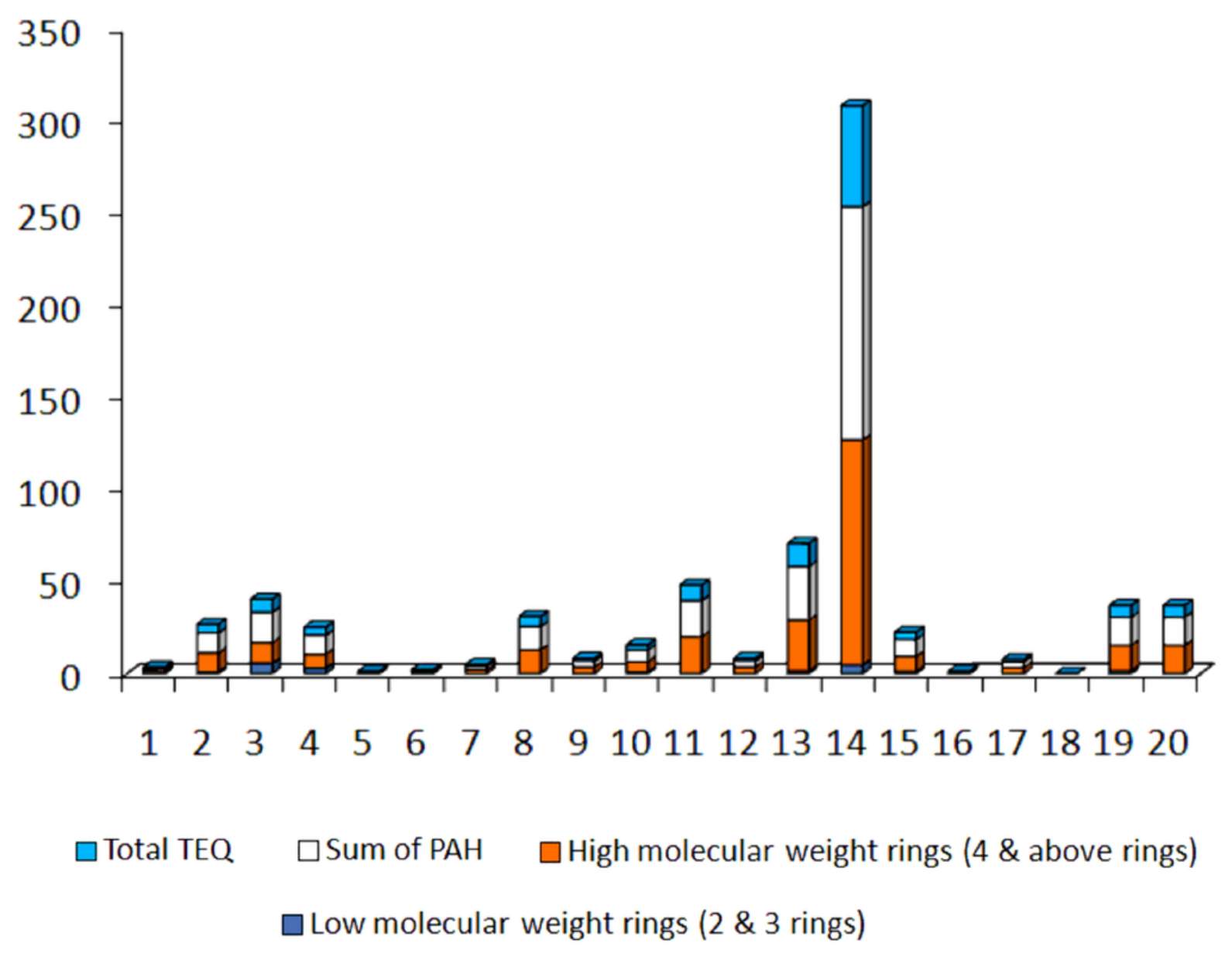

Figure 2

Distribution of total TEQ, Sum of PAH, low and high molecular weight ring PAHs in the surface sediments, selected estuaries of Kerala, Southwest coast of India 